\title{
Enhancement of Nutrients in Poultry Excreta through Formulated Microbial Consortium along with Bio Fertilizer Microorganisms
}

\author{
Pradeepkumar. K. V*, Arunadevi. P. S, Myvizhi. P \\ PG and Research Department of Zoology, Sri Vasavi College, Erode, Tamil Nadu, India
}

Received July 29, 2020; Revised September 18, 2020; Accepted October 19, 2020

\section{Cite This Paper in the following Citation Styles}

(a): [1] Pradeepkumar, K.V, Arunadevi. P.S, Myvizhi. P, "Enhancement of Nutrients in Poultry Excreta through Formulated Microbial Consortium along with Bio Fertilizer Microorganisms, "Advances in Zoology and Botany, Vol. 8, No. 6, pp. 491 - 505, 2020. DOI: 10.13189/azb.2020.080603.

(b): Pradeepkumar, K.V, Arunadevi. P.S, Myvizhi. P (2020). Enhancement of Nutrients in Poultry Excreta through Formulated Microbial Consortium along with Bio Fertilizer Microorganisms. Advances in Zoology and Botany, 8(6), 491 - 505. DOI: 10.13189/azb.2020.080603.

Copyright $\bigcirc 2020$ by authors, all rights reserved. Authors agree that this article remains permanently open access under the terms of the Creative Commons Attribution License 4.0 International License

\begin{abstract}
The present investigation deals with efficiency of the formulated microbial consortium on poultry excreta to enhance the macronutrient levels. In this context we have purchased selective strains of microbes from MTCC which effectively treat and enhance the nutrients level in manure. Usage of specific microbes could prove potential means of degrading some such complex environmental pollutants converts into available macronutrients through treatment. The poultry excreta were treated as such in the bare layer shed after shifted birds from the cages. The first shed was called control. There will be no treatment only sprayed chlorine free water to maintain the proper moisture level $(30-35 \%)$. In the second shed was treated with formulated microbial consortium, first week alone sprayed the consortium then weekly once sprayed chlorine free water to maintain proper moisture, in the third shed was treated with formulated microbial consortium together with biofertilizer microbes, first week sprayed formulated microbial consortium after fifteen days biofertilizer microbes had been sprayed and the rest of the weeks chlorine free water was sprayed to maintain the proper moisture level. After treatment physico chemical parameters had been analysed to evaluate the performance of the microbial consortium. The physico chemical analysis proved that the nutrients level was increased in the third poultry shed. Meanwhile, the composting time considerably decreased which increased the hope to treat poultry excreta effectively. The results
\end{abstract}

showed significant $(\mathrm{p}<0.05)$ differences within the amount of major total and available NPK levels.

Keywords Bio Fertilizer Microorganism, Formulated Microbial Consortium, Poultry Excreta, Agriculture

\section{Introduction}

The poultry farms are the fastest growing agro based industries in India and have been gradually increasing for a decade. Huge accumulations of poultry excreta that require to be properly managed to conserve the environment and public health. Manure produced from the excreta of poultry industry is currently applied to agricultural lands. Chastain et al. [1] reported that poultry manure contains major nutrients (NPK) is essential for plant growth, it's been well documented that it provides a valuable source to agriculture [2],[3]. Dauda et al., \& Drozdz et al., [4],[5] suggests the composition and therefore the content of nutrients in poultry manure was rich in nitrogen and also contains significant quantities of phosphorus and potassium, applied as a biofertilizer to boost up the fertility and physical properties of agricultural soil leading to increased crop yield.

According to Adeli et al., and Beckman [6],[7] the application of poultry manure enhances soil productivity, 
increases the soil organic carbon content, soil micro-organisms, improves soil crumb structure, the nutrient status of the soil, water holding capacity, oxygen diffusion rate, aggregate stability and enhances crop yield. Manure of poultry excreta is used commonly as a mulching material for agricultural and horticultural crops to conserve soil moisture and to guard against drying of the surface feeding roots during summer [8],[9]. Poultry excreta was extremely cheap and effective as an excellent source of nitrogen for sustainable crop production, but its availability remains a vital issue due to its bulky nature, while inorganic fertilizer isn't from now on any within the reach of poor-resource farmers because of its high cost [10]. Reason for the biofertilizer promotion was to avoid environmental hazard and sustainable growth of agriculture [11].

When managed correctly, land application of poultry manure is a viable way to recycle the major nutrients. But, making the manure from excreta of poultry is not an easy task because currently, poultry farms in India are facing a number of environmental problems like unpleasant odor, a huge number of house flies, maggots population, and another major problem is the accumulation of an enormous amount of wastes, especially excreta of birds generated by intensive production. Large scale accumulation of those wastes pose disposal, and pollution problems [12]. The typical daily fresh excreta production for broilers is about $43 \mathrm{~kg} / 1000 \mathrm{~kg}$ live weight [13]. However, pollution and nuisance problems can occur when incompletely decomposed poultry manure is applied under environmental conditions that don't favor agronomic utilization of the manure-borne nutrients [14]. Environmental concerns related to the land application of manure by-products from intensive animal operations include leaching losses of $\mathrm{N}$ in sub-surface drainage and to groundwater, contamination of surface water with soluble and particulate $\mathrm{P}$, reduced quality of air by the emission of gases and volatile organic compounds [15]. Air quality has become a significant environmental concern of the poultry industry [16]. Dust, odors, pathogenic microbes, endotoxins, and mycotoxins suspended in air, manure storage and land spreading of poultry litter is the problem of such industries [17].

Improperly managed poultry waste can have severe consequences for the environment like attraction of insect pests particularly house flies [18]. To regulate the flies and maggots, poultry farmers use highly toxic synthetic pesticides like pyrethrins and dichlorvos (DDVP). These practices would cause bird's excreta to be resistant to microbial degradation pose a serious problem for manure conversion. During chemical practices, uncontrolled decomposition of manure produces odorous gases, including dimethylamine, greenhouse gas, in addition to ketones, aldehydes, organic acids [19] and other compounds like mercaptans, sulphides, and disulfides. These noxious gases can cause respiratory diseases to birds and poultry workers [20]. Poultry manure can pose a potential threat to the health of human beings and have a harmful impact on the surrounding natural environment, particularly the soil and quality of water [19]. Ammonia volatilization from manure creates odor problems [21] and it inhibits the anaerobic digestion process [22],[23]. So improved manure handling and storage methods are needed to reduce the emission of those gases [24].

Improper conversion of poultry excreta into manure is the main source of pathogens. Bolan et al., [25] reported pathogenic populations are the most important problem for application of nitrogen rich poultry manure into the cultivable soil. While microbes perform different enzymatic and metabolic processes within the poultry excreta, two microbial populations that are an interesting group to the poultry industry are the nitrogen mineralization microbes and pathogens. Cook et al., and Rothrock et al., [26],[27] reported microbial load in poultry excreta can exceed $10^{10}$ cells $/ g$ and total microbial population nearly $90 \%$ was gram positive bacteria [28]. Pathogens represent the second group of bacteria of importance to the poultry industry. Culture-based and molecular-based work has shown that poultry litter could be a reservoir for several zoonotic pathogens [27].

There are a variety of treatment methods which are available to treat the poultry excreta by composting [29], anaerobic digestion [30], anaerobic co-digestion [31], thermophilic anaerobic digestion [32], Biogas production [33], fluidized bed combustion [34], Vermicomposting [35], etc., but every method has its own limitations. Hence innovative and easy technologies are required to treat the poultry excreta in a sustainable manner for every kind of poultry farm. It's been recognized quite recently that biological systems, primarily the usage of microbes, could prove potential means of degrading some such complex environmental pollutants, control obnoxious odor, and prevent pollution through treatment.

We employed the identical microbial technology in domestic solid waste management, our study revealed that the most important nutrients of available and total NPK analysis that the addition of formulated composting microbial consortium along with biofertilizer microorganism yield good nutritive manure effectively [36]. The one and the same technology was used for the poultry excreta management by using application of formulated microbial consortium for treating the poultry excreta in the present investigation. It's one among the innovative technologies, creates optimal conditions in layer sheds favor for decomposing microbes and quickly converts excreta into manure in all environmental conditions. Living microorganisms had been used to prepare bio fertilizer microbes (BFM) based on their metabolic activities which were responsible to produce and supply nutrients, influence the growth and physiology of the plants [37]. For the agricultural ecosystem, vital roles played by microbial populations could also be classified into four types viz., nitrogen fixing, phosphate 
solubilizing/mobilizing, composting, and biopesticides [38].

There have been many microbes which were existing naturally but the population was minimal to enhance a specific population of chosen microbes that have been artificially cultured and mixed-up with growth media which was suitable for proliferation. Present investigation there had been nine microbes that were employed in formulated microbial consortium (FMC) for the treatment and decomposition of poultry excreta and four bio fertilizer microbes (BFM) were used to have an influence on increasing the available major nutrients of NPK within the manure. The objective of the investigation was to evaluate the performance of formulated microbial consortium together with Bio fertilizer microorganism $(\mathrm{FMC}+\mathrm{BFM})$ on poultry excreta. This treatment system facilitated reduction of wastes and recycling of plant major nutrients and organic matter from poultry excreta to cultivate soils.

\section{Materials and Methods}

\section{Study Area}

The present investigation was carried out in the Dhanalakshmi poultry complex is located in Bewoor Koppal, Karnataka state, India (Latitude: $15^{\circ} 30^{\prime} 02.0^{\prime \prime} \mathrm{N}$ Longitude: $76^{\circ} 11^{\prime} 59.0^{\prime \prime} \mathrm{E}$ ) is selected for this study, prior to investigation the excreta were treated with various synthetic pesticides to control the odor, flies and maggots population. There are about 5,00,000 layer birds and the approximate excreta production is 20 tons/day. Insecticide application for control odor, flies and its maggots in the poultry could prevent the microbial decomposition of poultry excreta. So, we advised the management to stop the application of hazardous pesticide and go for eco friendly formulated microbial consortium treatment method. The concerned management willing to accept microbial consortium treatment, they stopped the application of synthetic pesticide one month before the microbial consortium treatment. The poultry excreta was treated as such in the bare layer shed after birds shifted from the cages (Fig.1). First shed was called poultry manure - I control (PM - I control) there will be no treatment only sprayed chlorine free water to maintain the proper moisture level (30-35\%). In the second shed was poultry manure - II treated with formulated microbial consortium (PM - II FMC treated), first week alone sprayed the consortium then weekly once sprayed chlorine free water to maintain proper moisture, in the third shed was poultry manure - III (PM III FMC+BFM treated) treated with formulated microbial consortium together with biofertilizer microbes, first week sprayed formulated microbial consortium after fifteen days biofertilizer microbes had been sprayed and the rest of the weeks chlorine free water was sprayed to maintain the proper moisture level(Fig.1). After 42 days to 84 days weekly once a test sample had been taken from all the sheds and send to the laboratory for physico chemical parameter analysis.

\section{Description of Formulated Microbial Consortium (FMC)}

FMC+BFM consortium used in this investigation was with the locally available microorganisms in poultry farms. The FMC contains diverse kinds of bacterial species. These microorganisms were purchased from Microbial Type Culture Collection Center (MTCC), Chandigarh, India and grown in specific media as per MTCC recommendation. They are: (i) control pathogens we are using Lactobacillus fermentum and (ii) Lactobacillus bifermentans [39],[40],[41], (iii) pesticide residue degraded by using of Rhodopseudomonas sp., [42] (iv) will degrade the cellulose material by using of Cellulomonas fimi [43] (v) degrade the pollutants, oxidizing tolerant efficiency and can suppress the pathogen activity by using of Psudomonas fluorescens [44] and also the fungal species are (vi) Saccharomyces cerevisiae for fermenting organic matters [45], entomopathogenic fungus (vii) Beauveria bassiana was used to control flies in poultry farm [46] (viii) white rot fungus of Phanerochaete chrysoporium for treating hazardous chemicals and wastes present in poultry excreta and it could degrade broad range of organic and chlorinated organic compounds [47], and (ix) high biodegradation activity we using Mucor hiemalis [48].

\section{Description of Bio Fertilizer Microorganisms (BFM)}

The biofertilizer microorganisms contain four different kinds of microbes which are commercially available, commonly used to solubilize the nitrogen, phosphorus and potash within the given substrates. They're (i) Azospirillum orizae having the power to solubilize inorganic phosphorus and improves the uptake of nutrients by plants [49],[50], (ii) Rhizobium leguminosarum used for nitrogen fixing [51], (iii) for xylanase production using Bacillus megaterium [52], and (iv) Frateuria aurantia was used for solubilizing Potash in poultry excreta [53].

\section{Description of Formulated microbial consortium and Biofertilizer microorganism}

All microbes were cultured through specific media as per the MTCC protocol (Table 1) After that, the culture was transferred to the media which has common nutrients for all microbes found in FMC and BFM. After the incubation microbial solution was ready for the treatment. The reason for choosing this FMC was naturally occurring non-toxic mixture of beneficial microbes having the ability to quickly consume and digest a variety of organic matter, which is not harmful to human or to the poultry birds (non-pathogenic), reproduces quickly in the conditions present in poultry farm and efficiently removes foul odor, 
wide range of $\mathrm{pH}$ and temperature tolerance, co-existing nature and facultative anaerobic which can survive in both aerobic and anaerobic conditions.

\section{Preparation of microbial solution for field applications}

The FMC and FMC + BFM were prepared in the form of individual mother culture. The cell count within the mother culture was around $10^{9} \mathrm{CFU}$. Then it has been mixed equally and makes it a combined mother culture. The combined mother culture was extended or activated. Previously the barrel was washed with chlorine free water and dried in sunlight for application solution production. Cleaned barrel was filled with $1 \mathrm{~L}$ mother culture and was mixed with 50L of chlorine free water (1:50) and $800 \mathrm{gm}$ of cane sugar (Jaggery) in a pre formulated ratio. The mixture was kept for 7 days under anaerobic conditions and is named application culture. The character of application cultures $\mathrm{pH}$ range is $5-6.5$, Straw yellow to Dark brown in colour, slightly souring odor, Density is around 1.0. The cell count FMC and FMC + BFM were around $10^{6} \mathrm{CFU}$ (Table.1). After seven days it became the application culture.

\section{Sampling and Analysis}

From 42 days to 84 days weekly once three samples were taken from each shed. The first sample was stored at $4^{0} \mathrm{C}$ to provide a sample library. The second sample was kept in shadow dry, made as a powder then sieved in $4 \mathrm{~mm}$ sieve and taken into the laboratory for physicochemical analysis. At each sampling period, the $\mathrm{pH}$ was determined using Elico LI120 model $\mathrm{pH}$ meter (1:10, water: extract), Electrical Conductivity was determined using Elico $\mathrm{CM}$ 180 model EC meter. Both $\mathrm{pH}$, and EC, was carried out following the procedures of the standard methods for the examination of water and wastewater [54]. The basic parameters and macronutrients of the samples were determined, including the organic carbon [55], nitrogen [56], potassium [57], and phosphate [58] concentrations.

Table 1. Microbes of Formulated Microbial Consortium Solution Procurement and Sub Culture Methods

\begin{tabular}{|c|c|c|c|c|c|}
\hline $\begin{array}{l}\text { S1. } \\
\text { No }\end{array}$ & Microbial species & $\begin{array}{l}\text { Cell Count } \\
(\text { Cells/ml })\end{array}$ & $\begin{array}{l}\text { Culture Procurement \& } \\
\text { Code }\end{array}$ & Sub - Culture Media & $\begin{array}{c}\text { Culture } \\
\text { media code }\end{array}$ \\
\hline \multicolumn{6}{|c|}{ Bacterial Species } \\
\hline 1 & Lactobacillus fermentum & $\begin{array}{r}1.3 \times 10^{9} \\
\text { Cells } / \mathrm{ml} \\
\end{array}$ & $\begin{array}{l}\text { Lyophilized Powder } \\
\text { MTCC903 }\end{array}$ & $\begin{array}{c}\text { MRS Broth (Hi-Media, India) } \\
\left(\mathrm{pH} @ 25^{\circ} \mathrm{C} 6.5 \pm 0.2\right)\end{array}$ & M369 \\
\hline 2 & $\begin{array}{l}\text { Lactobacillus } \\
\text { bifermentans }\end{array}$ & $\begin{array}{r}1.2 \times 10^{9} \\
\text { Cells } / \mathrm{ml} \\
\end{array}$ & $\begin{array}{c}\text { Lyophilized Powder } \\
\text { MTCC-3818 }\end{array}$ & $\begin{array}{c}\text { MRS Broth (Hi-Media, India) } \\
\left(\mathrm{pH} @ 25^{\circ} \mathrm{C} 6.5 \pm 0.2\right)\end{array}$ & M369 \\
\hline 3 & Rhodopseudomonas sp. & $\begin{array}{c}1.4 \times 10^{9} \\
\text { Cells } / \mathrm{ml}\end{array}$ & $\begin{array}{l}\text { Seed Culture } \\
\text { MTCC- } 8756\end{array}$ & $\begin{array}{c}\text { YPS Medium }(0.3 \% \text { yeast extract, } \\
0.3 \% \text { peptone, } 10 \mathrm{mM} \text { succinate, } 100 \\
\text { mM MOPS at } \mathrm{pH} 7.0)\end{array}$ & -- \\
\hline 4 & Cellulomonas fimi & $\begin{array}{r}1.3 \times 10^{9} \\
\text { Cells } / \mathrm{ml} \\
\end{array}$ & $\begin{array}{l}\text { Seed Culture } \\
\text { MTCC-24 }\end{array}$ & $\begin{array}{c}\text { Dubos Broth Base (Hi-Media, India) } \\
\left(\mathrm{pH} @ 25^{\circ} \mathrm{C} 6.5 \pm 0.2\right)\end{array}$ & M067 \\
\hline 5 & Psudomonas fluorescens & $\begin{array}{l}1.3 \times 10^{9} \\
\text { Cells } / \mathrm{ml}\end{array}$ & $\begin{array}{l}\text { Seed Culture } \\
\text { MTCC-664 }\end{array}$ & $\begin{array}{c}\text { Nutrient agar (Hi-Media, India) } \\
\left(\mathrm{pH} @ 25^{\circ} \mathrm{C} 7.3 \pm 0.1\right)\end{array}$ & MM012 \\
\hline \multicolumn{6}{|c|}{ Fungal Species } \\
\hline 1 & $\begin{array}{l}\text { Saccharomyces } \\
\text { cerevisiae }\end{array}$ & $\begin{array}{l}1.6 \times 10^{9} \\
\text { Cells } / \mathrm{ml}\end{array}$ & $\begin{array}{c}\text { Powder } \\
\text { MTCC-212 }\end{array}$ & $\begin{array}{c}\text { Sabouraud Dextrose Broth, Granulated } \\
\text { (Hi-Media, India) } \\
\text { (pH after sterilization } \\
\text { @ } 25^{\circ} \mathrm{C} 5.6 \pm 0.2 \text { ) } \\
\end{array}$ & GMH033 \\
\hline 2 & Beauveria bassiana & $\begin{array}{l}1.2 \times 10^{9} \\
\text { Cells } / \mathrm{ml}\end{array}$ & $\begin{array}{c}\text { Powder } \\
\text { MTCC-4492 }\end{array}$ & $\begin{array}{c}\text { Potato Dextrose Broth } \\
\text { (Hi-Media, India) } \\
\text { pH @ } 25^{\circ} \mathrm{C} 5.1 \pm 0.2 \\
\end{array}$ & M403 \\
\hline 3 & $\begin{array}{l}\text { Phanerochaete } \\
\text { chrysoporium }\end{array}$ & $\begin{array}{l}1.3 \times 10^{9} \\
\text { Cells } / \mathrm{ml} \\
\end{array}$ & $\begin{array}{c}\text { Freeze dried culture } \\
\text { MTCC- } 787\end{array}$ & 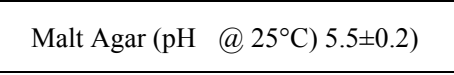 & M253 \\
\hline 4 & Mucor hiemalis & $\begin{array}{l}1.3 \times 10^{9} \\
\text { Cells } / \mathrm{ml}\end{array}$ & $\begin{array}{l}\text { Seed Culture } \\
\text { MTCC - } 157\end{array}$ & $\begin{array}{c}\text { Potato Dextrose Broth } \\
\text { (Hi-Media, India) } \\
\mathrm{pH} @ 25^{\circ} \mathrm{C} 5.1 \pm 0.2 \\
\end{array}$ & M403 \\
\hline \multicolumn{6}{|c|}{ Bio Fertilizer Microorganisms Procurement and Sub Culture Methods } \\
\hline 1 & Azospirillum orizae & $\begin{array}{l}1.3 \times 10^{9} \\
\text { Cells } / \mathrm{ml}\end{array}$ & $\begin{array}{l}\text { Seed Culture } \\
\text { MTCC- } 9757\end{array}$ & $\begin{array}{c}\text { Azospirillum Medium w/ 0.17\% Agar } \\
\text { (Twin Pack) (Hi-Media, India) } \\
\text { pH @ } 25^{\circ} \mathrm{C} 6.8 \pm 0.2 \\
\end{array}$ & M518 \\
\hline 2 & $\begin{array}{c}\text { Rhizobium } \\
\text { leguminosarum }\end{array}$ & $\begin{array}{l}1.2 \times 10^{9} \\
\text { Cells } / \mathrm{ml}\end{array}$ & $\begin{array}{l}\text { Seed Culture } \\
\text { MTCC-99 }\end{array}$ & $\begin{array}{c}\text { Yeast Mannitol Broth } \\
\text { (Hi-Media, India) } \\
\text { pH @ } 25^{\circ} \mathrm{C} 6.8 \pm 0.2\end{array}$ & M716 \\
\hline 3 & Bacillus megaterium & $\begin{array}{l}1.4 \times 10^{9} \\
\text { Cells } / \mathrm{ml}\end{array}$ & $\begin{array}{l}\text { Seed Culture } \\
\text { MTCC- } 2444\end{array}$ & $\begin{array}{c}\text { HiCrome }^{\mathrm{TM}} \text { Bacillus Agar Intended use } \\
\text { (Hi-Media, India) } \\
\mathrm{pH} @ 25^{\circ} \mathrm{C} 7.1 \pm 0.2 \\
\end{array}$ & M1651 \\
\hline 4 & Frateuria aurantia & $\begin{array}{l}1.3 \times 10^{9} \\
\text { Cells } / \mathrm{ml}\end{array}$ & $\begin{array}{c}\text { Seed Culture } \\
\text { (OMEGA Ecotech, } \\
\text { Coimbatore, TN, India) }\end{array}$ & $\begin{array}{c}\text { Mannitol Salt Agar } \\
\text { (Hi-Media, India) } \\
\text { pH @ } 25^{\circ} \mathrm{C} 7.4 \pm 0.2\end{array}$ & M118 \\
\hline
\end{tabular}




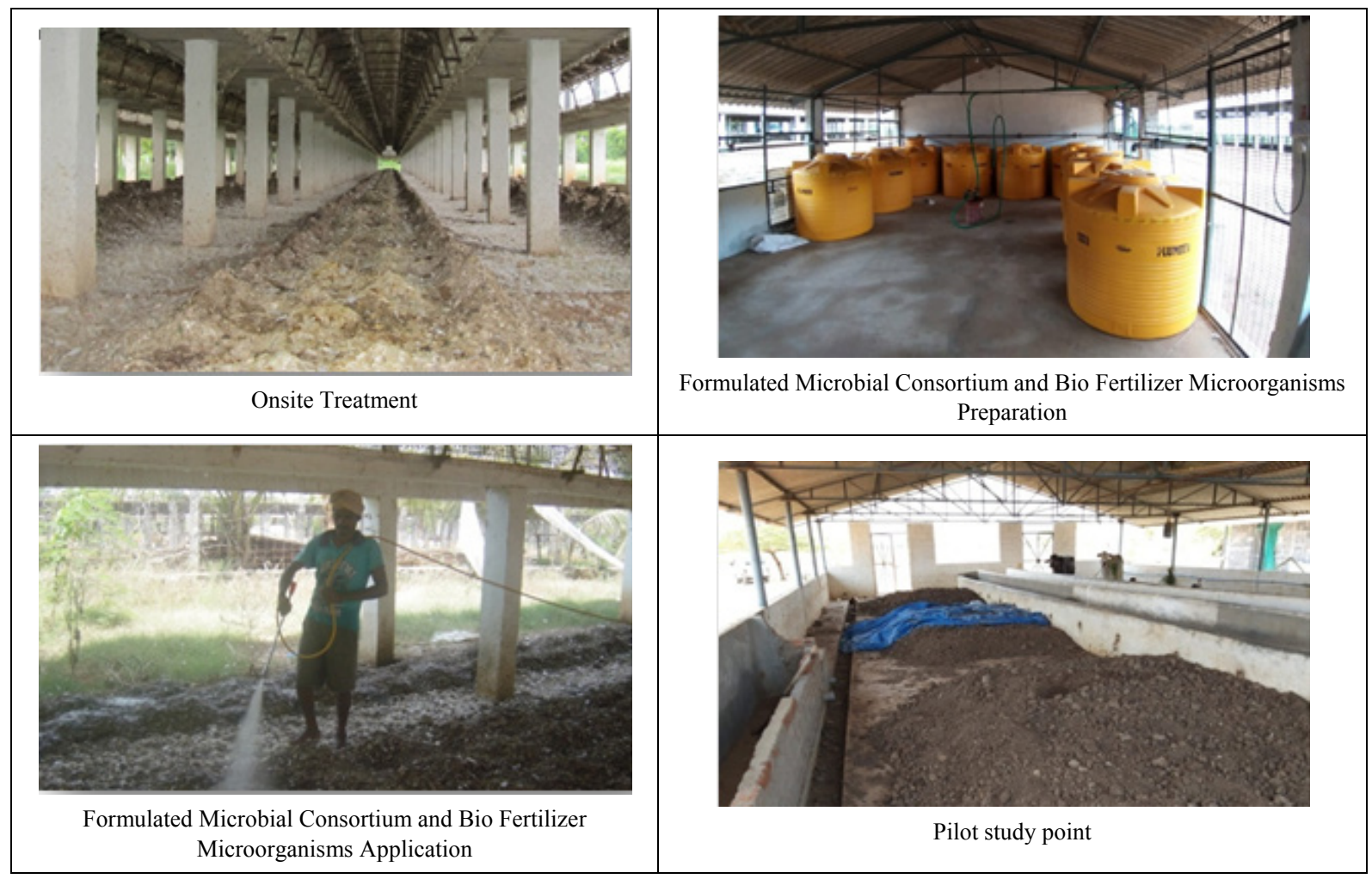

Figure 1. Treatment of poultry excreta, FMC, BFM Preparation and Application

\section{Statistical Analysis}

All experiments were conducted in triplicate. The values reported in this study are mean $\pm \mathrm{SD}$ and one way ANOVA of variance, the significant means were compared and a $\mathrm{p}<0.05$ was considered as statistically significant analysis.

\section{Results}

\subsection{Physico-chemical Parameters and Macronutrients}

The variation of important parameters such as $\mathrm{pH}, \mathrm{EC}$, Organic carbon, C:N Ratio, and Macronutrients level in PM - I control, PM - II FMC treated and PM - III FMC+BFM treated were present in Table.2. In this study the result shows a significant difference among the composts at 0.05 levels of significance (Table.3). The $\mathrm{pH}$ was $6.5 \pm 0.19$ for PM - I control, $8.2 \pm 0.26$ for PM - II FMC treated, and $8.18 \pm 0.59$ for PM - III - FMC+BFM treated. The EC of PM-I Control was $3.23 \pm 0.13 \mathrm{mS} / \mathrm{cm}$, PM - II treated with FMC was $3.8 \pm 0.47 \mathrm{mS} / \mathrm{cm}$, PM - III treated with $\mathrm{FMC}+\mathrm{BFM}$ was $4.15 \pm 0.44 \mathrm{mS} / \mathrm{cm}$. The composts organic carbon levels in PM-I control, PM - II treated with FMC and the PM - III treated with FMC+BFM were $12.88 \pm 0.63 \%, 12.25 \pm 0.7 \%$ and $11.6 \pm 0.9 \%$, respectively.

The total nitrogen content of the PM-I control was $1.13 \pm 0.08 \%$, PM - II treated with FMC was $1.3 \pm 0.06 \%$ and
PM - III treated with FMC+BFM was $1.37 \pm 0.04 \%$. The Total phosphorus content of the PM - I control was $0.48 \pm 0.08 \%$, PM - II treated with FMC was $0.67 \pm 0.05 \%$ and PM - III treated with FMC+BFM was $0.73 \pm 0.04 \%$. The potassium of the PM - I control, PM - II treated with FMC and PM -III treated with FMC+BFM were $0.51 \pm 0.08 \%, 0.71 \pm 0.05 \%$ and $0.73 \pm 0.05 \%$, respectively.

The available nitrogen content of the PM - I control was $0.34 \pm 0.04 \%$, PM - II treated with FMC was $0.43 \pm 0.06 \%$ and PM - III treated with FMC+BFM was $0.48 \pm 0.09 \%$. The available phosphorus content of the PM - I control was $0.16 \pm 0.04 \%$, PM - II treated with FMC was $0.22 \pm 0.04 \%$ and PM - III treated with FMC+BFM was $0.26 \pm 0.06 \%$. The available potassium level was increased in all composts with the increasing composting period. High rate of increase was observed in PM-III treated with FMC+BFM $0.04 \pm 0.01 \%$. In PM-II treated with FMC potassium content was $0.03 \pm 0.003 \%$ and the rate at the PM - I control was $0.03 \pm 0.01 \%$. The C:N ratio in PM - I control was $40.9 \pm 7.42$, PM-II treated with FMC was $35.3 \pm 05.9$, and PM-III treated with FMC+BFM was $28.23 \pm 6.14$.

The obtained F-ratio value of parameters shown in Table. 3 was higher than the table values with df 2 and 9 required for significance at 0.05 level except organic carbon and C:N ratio. Since the value of F-ratio is higher than the table value, it indicates that there was a significant difference among the groups of PM II-FMC Treated, PM III-FMC+BFM Treated and PM - I control group. 
Table 2. Descriptive results of Physico- chemical and Macro nutrients parameters level in PM - I Control, PM - II FMC treated and PM - III FMC+ BFM

\begin{tabular}{|c|c|c|c|}
\hline \multirow{2}{*}{ Parameters } & \multicolumn{3}{|c|}{ Treatment Groups } \\
\cline { 2 - 4 } & PM I- Control & PM II - FMC Treated & PM III-FMC+BFM Treated \\
\hline \multicolumn{3}{|c|}{ Mean \pm SD } \\
\hline pH & $6.5 \pm 0.19$ & $8.2 \pm 0.26$ & $8.18 \pm 0.59$ \\
\hline EC(mS/cm ) & $3.23 \pm 0.13$ & $3.8 \pm 0.47$ & $4.15 \pm 0.44$ \\
\hline OC(\%) & $12.88 \pm 0.63$ & $12.25 \pm 0.7$ & $11.6 \pm 0.9$ \\
\hline Total (\%) & $1.13 \pm 0.08$ & $1.3 \pm 0.06$ & $0.37 \pm 0.04$ \\
\hline Total P (\%) & $0.48 \pm 0.08$ & $0.67 \pm 0.05$ & $0.73 \pm 0.05$ \\
\hline Total K (\%) & $0.51 \pm 0.08$ & $0.71 \pm 0.05$ & $0.48 \pm 0.09$ \\
\hline Available N (\%) & $0.34 \pm 0.04$ & $0.43 \pm 0.06$ & $0.26 \pm 0.06$ \\
\hline Available P (\%) & $0.16 \pm 0.04$ & $0.22 \pm 0.04$ & $0.04 \pm 0.01$ \\
\hline Available K (\%) & $0.03 \pm 0.01$ & $0.03 \pm 0.003$ & $28.23 \pm 6.14$ \\
\hline C:N Ratio & $40.9 \pm 7.42$ & $35.3 \pm 05.9$ & \\
\hline
\end{tabular}

Table 3. ANOVA results shows significant variations among the PM - I Control, PM - II FMC treated and PM - III FMC+ BFM treated poultry excreta indicate enhancement of nutrients and compost maturity

\begin{tabular}{|c|c|c|c|c|c|c|c|c|}
\hline \multirow[b]{2}{*}{ Sl. No } & \multirow[b]{2}{*}{ Parameters } & \multirow[b]{2}{*}{ Treatment Groups } & \multicolumn{6}{|c|}{ ANOVA } \\
\hline & & & \multicolumn{2}{|c|}{ Sum of Squares } & df & Mean Square & $\mathrm{F}$ & *Sig. \\
\hline \multicolumn{9}{|c|}{ Physico-chemical Parameters \& Macronutrients } \\
\hline \multirow{3}{*}{1} & \multirow{3}{*}{$\mathrm{pH}$} & PM I - Control & BG & 7.15 & 2 & 3.58 & \multirow{3}{*}{24.06} & \multirow{3}{*}{$0.00^{*}$} \\
\hline & & PM II - FMC Treated & WG & 1.34 & 9 & 0.15 & & \\
\hline & & PM III-FMC+BFM Treated & $\mathrm{T}$ & 8.49 & 11 & & & \\
\hline \multirow{3}{*}{2} & \multirow{3}{*}{$\mathrm{EC}(\mathrm{mS} / \mathrm{cm})$} & PM I - Control & BG & 1.72 & 2 & 0.86 & \multirow{3}{*}{5.93} & \multirow{3}{*}{$0.02 *$} \\
\hline & & PM II - FMC Treated & WG & 1.30 & 9 & 0.14 & & \\
\hline & & PM III-FMC+BFM Treated & $\mathrm{T}$ & 3.02 & 11 & & & \\
\hline \multirow{3}{*}{3} & \multirow{3}{*}{ OC $(\%)$} & PM I - Control & $\mathrm{BG}$ & 3.25 & 2 & 1.63 & \multirow{3}{*}{2.87} & \multirow{3}{*}{0.11} \\
\hline & & PM II - FMC Treated & WG & 5.10 & 9 & 0.57 & & \\
\hline & & PM III-FMC+BFM Treated & $\mathrm{T}$ & 8.35 & 11 & & & \\
\hline \multirow{3}{*}{4} & \multirow{3}{*}{ Total N (\%) } & PM I - Control & BG & 0.12 & 2 & 0.06 & \multirow{3}{*}{16.40} & \multirow{3}{*}{$0.00 *$} \\
\hline & & PM II - FMC Treated & WG & 0.03 & 9 & 0.00 & & \\
\hline & & PM III-FMC+BFM Treated & $\mathrm{T}$ & 0.16 & 11 & & & \\
\hline \multirow{3}{*}{5} & \multirow{3}{*}{ Total P (\%) } & PM I - Control & BG & 0.06 & 2 & 0.03 & \multirow{3}{*}{11.71} & \multirow{3}{*}{$0.00^{*}$} \\
\hline & & PM II - FMC Treated & WG & 0.02 & 9 & 0.00 & & \\
\hline & & PM III-FMC+BFM Treated & $\mathrm{T}$ & 0.08 & 11 & & & \\
\hline \multirow{3}{*}{6} & \multirow{3}{*}{ Total K (\%) } & PM I - Control & BG & 0.03 & 2 & 0.01 & & \\
\hline & & PM II - FMC Treated & WG & 0.03 & 9 & 0.00 & 4.42 & $0.05^{*}$ \\
\hline & & PM III-FMC+BFM Treated & $\mathrm{T}$ & 0.05 & 11 & & & \\
\hline & & PM I - Control & BG & 0.04 & 2 & 0.02 & & \\
\hline 7 & Available N (\%) & PM II - FMC Treated & WG & 0.04 & 9 & 0.00 & 4.58 & $0.04 *$ \\
\hline & & PM III-FMC+BFM Treated & $\mathrm{T}$ & 0.08 & 11 & & & \\
\hline & & PM I - Control & BG & 0.02 & 2 & 0.01 & & \\
\hline 8 & Available P (\%) & PM II - FMC Treated & WG & 0.02 & 9 & 0.00 & 5.20 & $0.03 *$ \\
\hline & & PM III-FMC+BFM Treated & $\mathrm{T}$ & 0.04 & 11 & & & \\
\hline & & PM I - Control & BG & 0.00 & 2 & 0.00 & & \\
\hline 9 & Available K (\%) & PM II - FMC Treated & WG & 0.00 & 9 & 0.00 & 5.68 & $0.03 *$ \\
\hline & & PM III-FMC+BFM Treated & $\mathrm{T}$ & 0.00 & 11 & & & \\
\hline & & PM I - Control & BG & 322.50 & 2 & 161.2 & & \\
\hline 10 & C:N Ratio & PM II - FMC Treated & WG & 381.20 & 9 & 42.35 & 3.81 & 0.06 \\
\hline & & PM III-FMC+BFM Treated & $\mathrm{T}$ & 703.70 & 11 & & & \\
\hline
\end{tabular}

Source: Calculated data $\mid \mathrm{BG}=$ Between Groups $\mid \mathrm{WG}=$ Within Groups $\mid \mathrm{T}=$ Total $\mid$

* Significant at 0.05 level - NS=Not significant | F - Table Value (0.05\%)

Among the all experiments Organic carbon and C:N Ratio were insignificant. Other parameters were well within the significant value at $0.05 \%$ 


\section{Graphical Analysis}

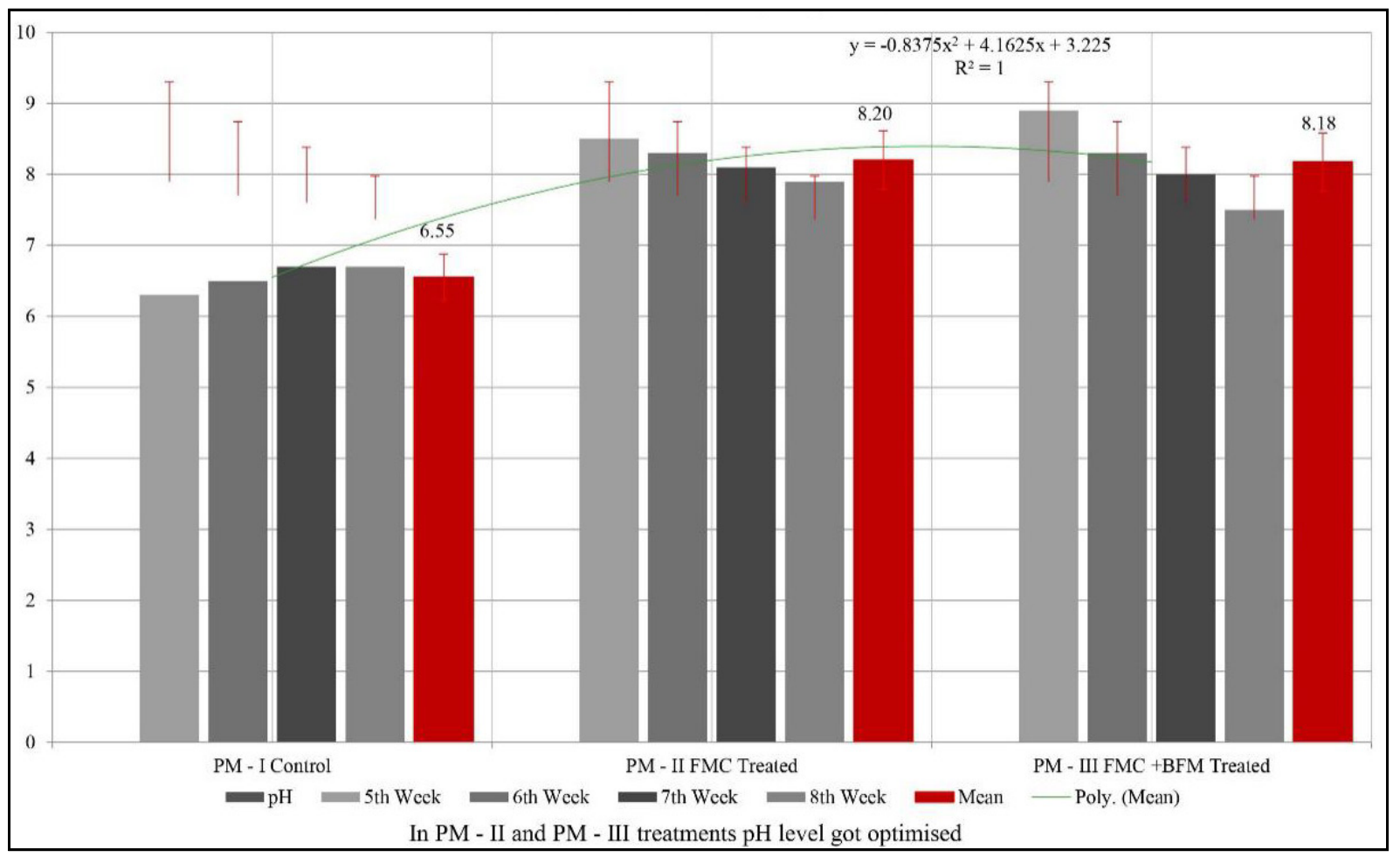

Figure 2. Periodic variations in $\mathrm{pH}$ at different stages and treatment of PM-1 Control, PM-II FMC treated and PM-III FMC+BFM treated poultry excreta

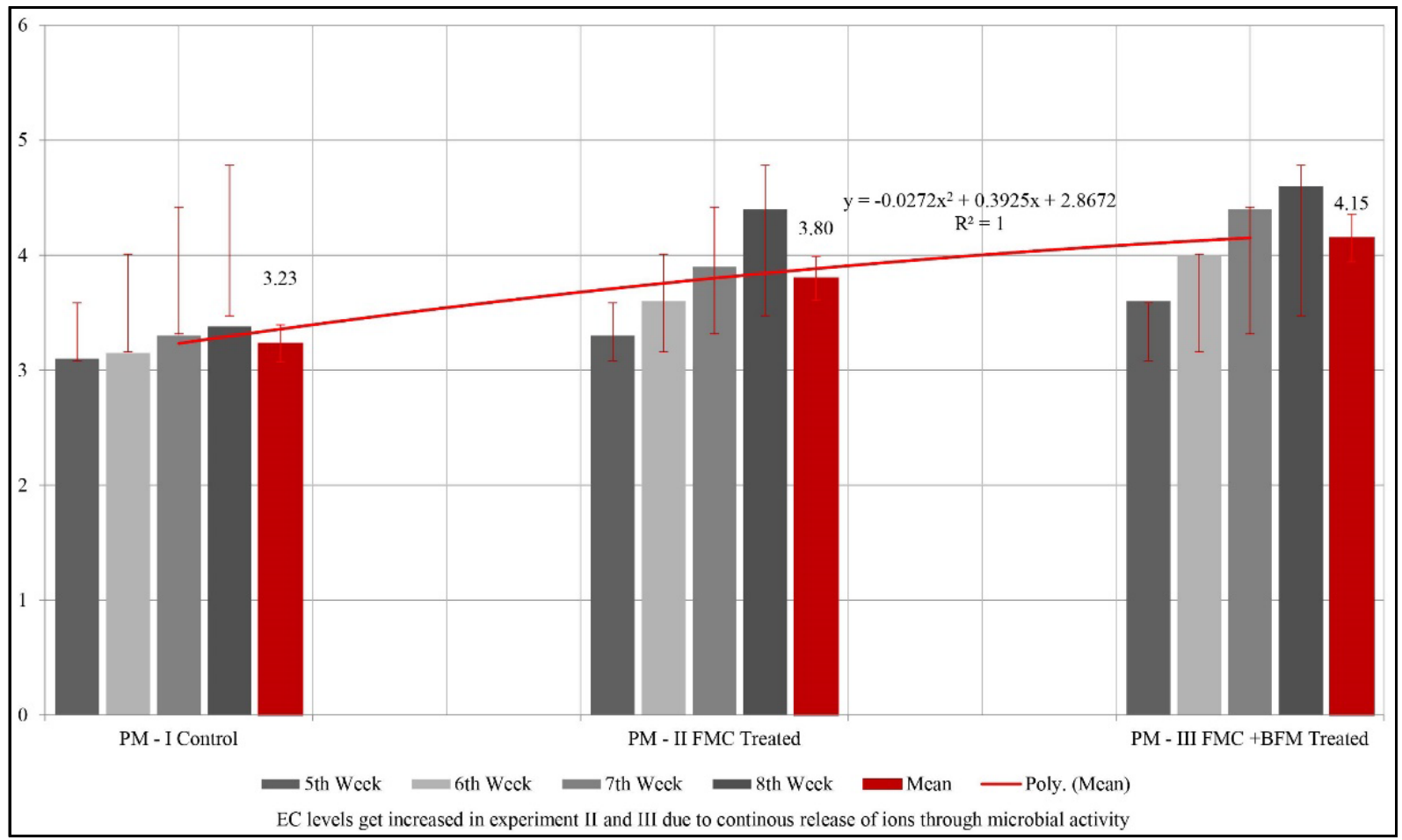

Figure 3. Periodic variations of Electrical Conductivity at different treatment stages of PM-I Control, PM-II FMC treated and PM-III FMC+BFM treated poultry excreta 


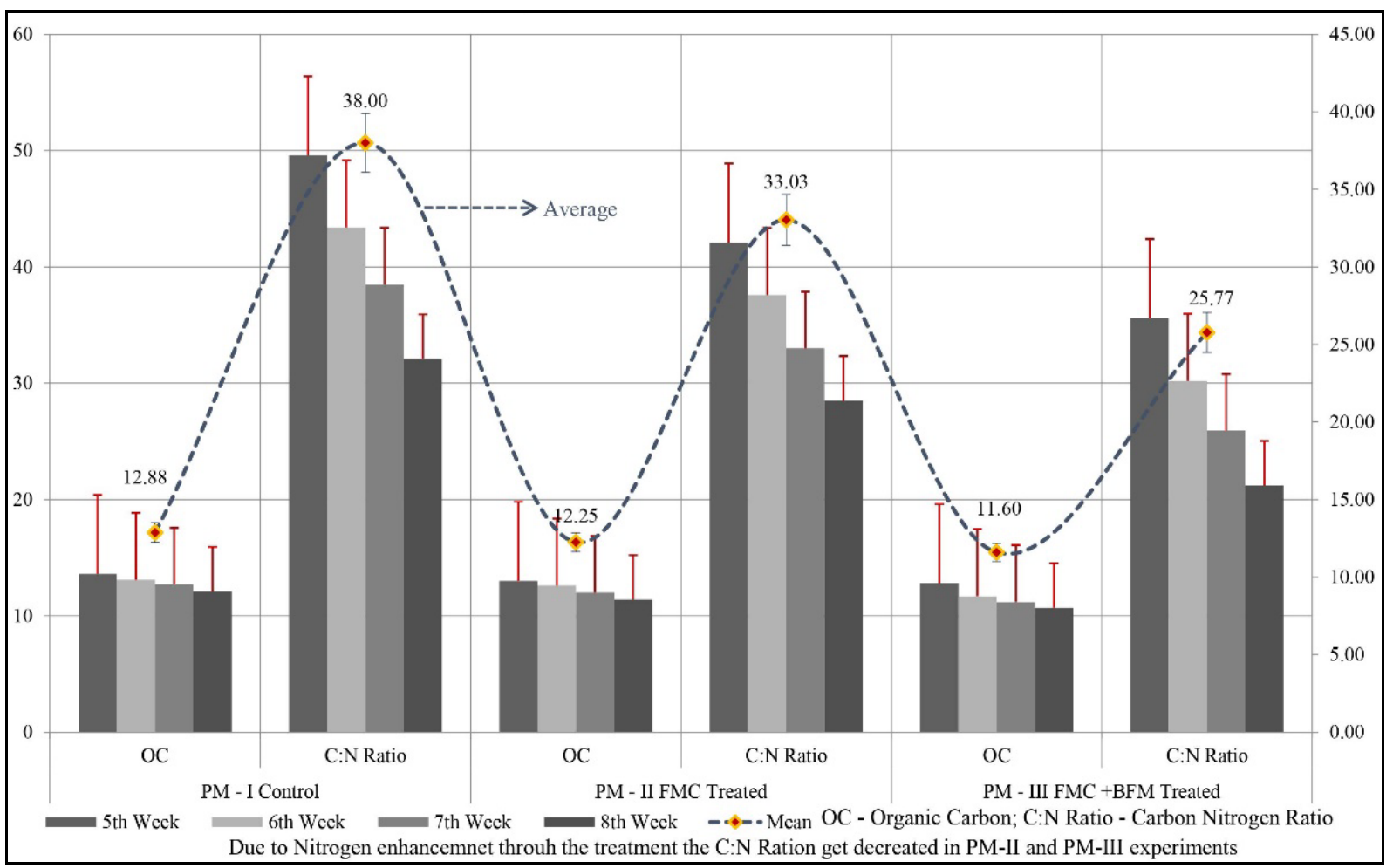

Figure 4. Variations of Organic Carbon and C:N Ratio during the treatment period of $5^{\text {th }}$ week to $8^{\text {th }}$ week composting of PM-I Control, PM-II FMC treated, PM-III FMC+BFM treated poultry excreta

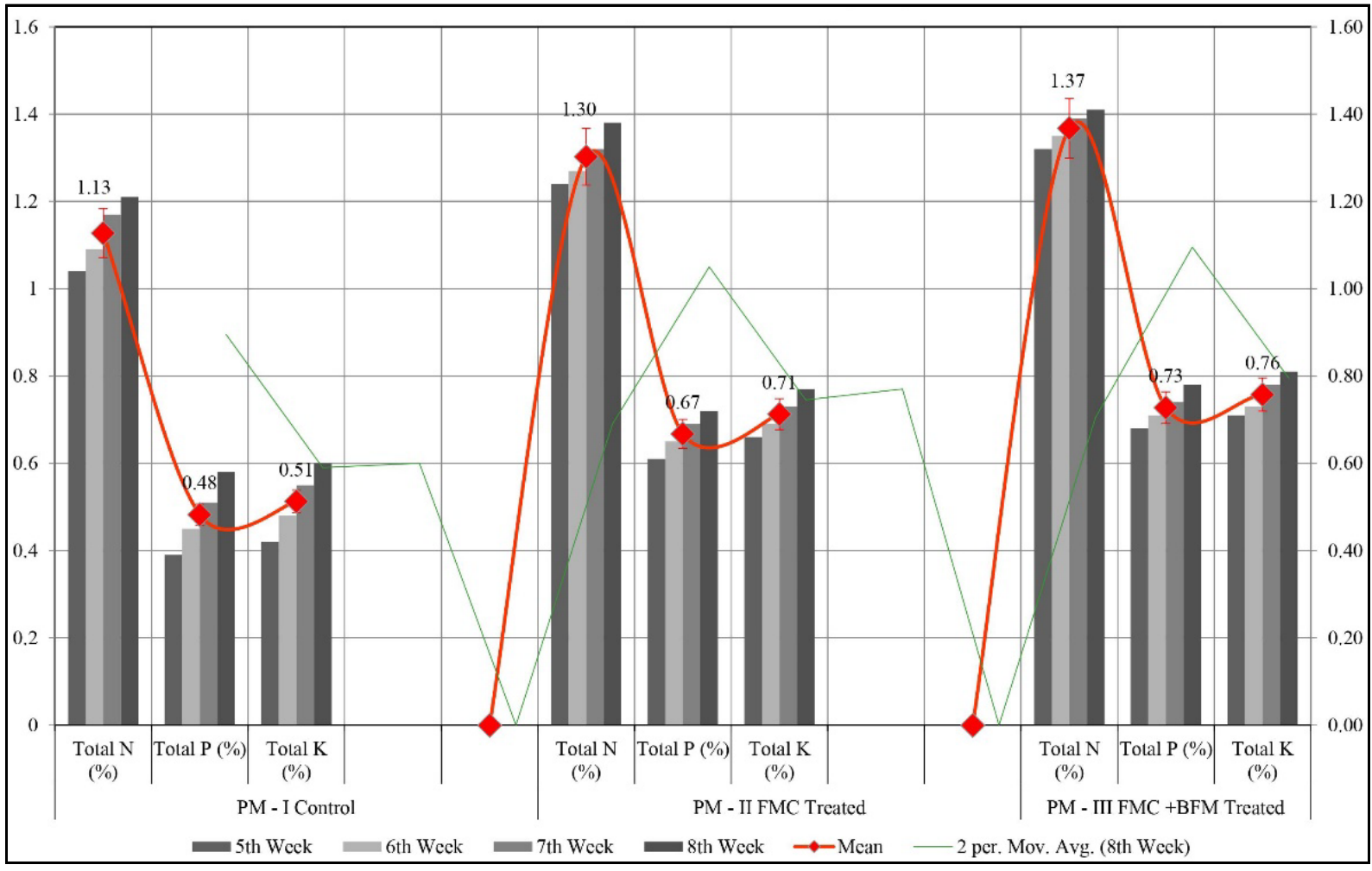

Figure 5. Total NPK enhancement during the treatment period of $5^{\text {th }}$ week to $8^{\text {th }}$ week analysis of PM-I Control, PM-II FMC treated, PM-III FMC+BFM treated poultry excreta 


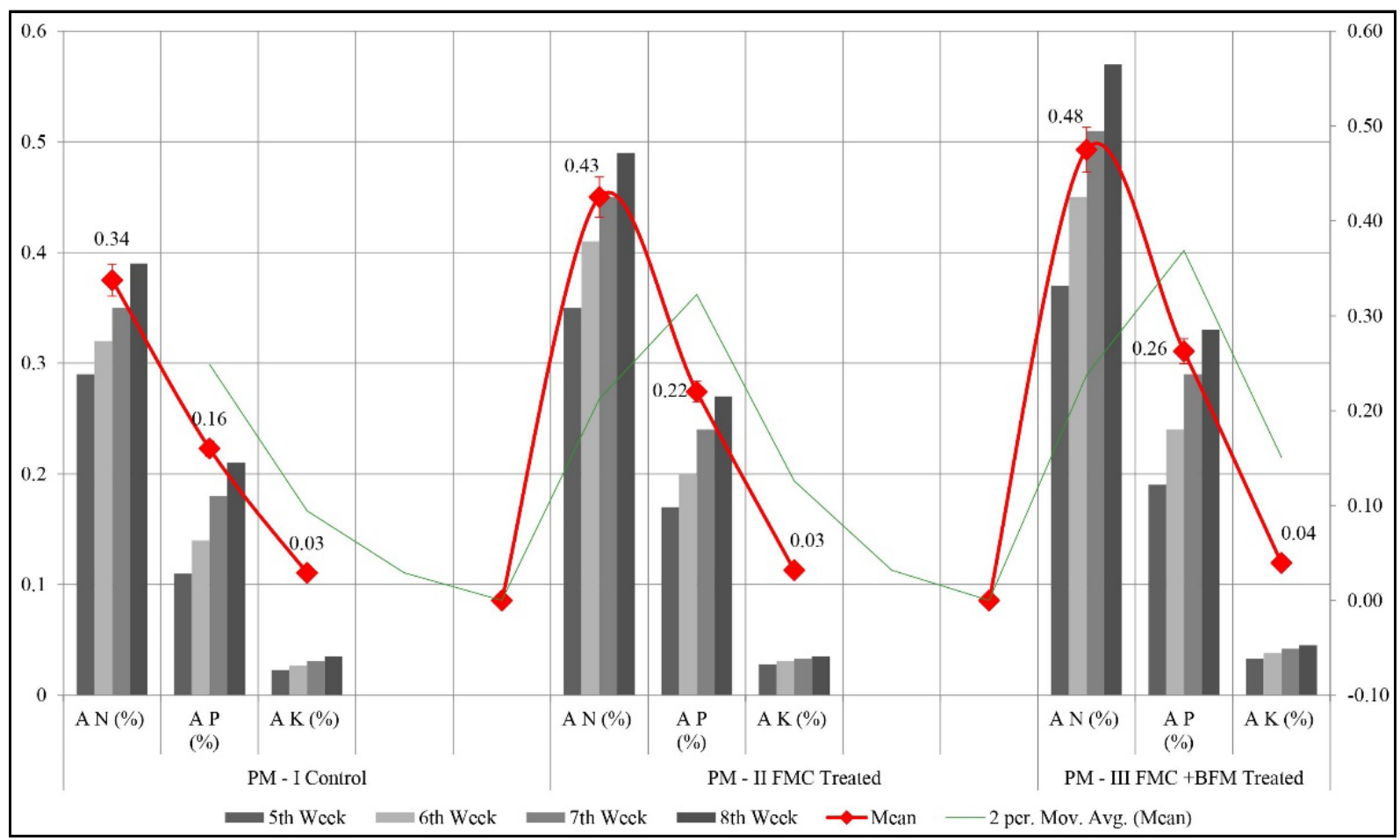

Figure 6. Available NPK enhancement during the treatment period of $5^{\text {th }}$ week to $8^{\text {th }}$ week analysis of PM-I Control, PM-II FMC treated, PM-III FMC + BFM treated poultry excreta

\section{Discussion}

Available forms of nutrients present in poultry manure are among the highest when compared to all other manures, such as cow dung, vermicompost and the use of poultry manure can provide adequate quantities of all essential plant nutrients. So the present study was envisioned to treat the poultry excreta converting to effective and nutrient enriched manure through FMC and FMC+BFM treatment. The results obtained from our study are discussed in this section. Composting of poultry excreta prior to application as a fertilizer is recommended to control the spread of pathogens, minimize the production of phytotoxic substances, control pesticide residues, and reduce unpleasant odors [59],[60],[61].

During poultry excreta treatment microbes of Rhodopseudomonas sp., and Pseudomonas fluorescens present in FMC role was important because several species of Rhodopseudomonas sp., have been demonstrated to have the ability to degrade various synthetic pyrethroids, and DDVP. Luo et al.,[62] reported encoding genes of 2OG-Fe(II) oxygenase enzyme of Rhodopseudomonas $s p$. PSB07-21 having capability of degrading synthetic pyrethroids. Selimoglu et al., [63] reported Rhodopseudomonas $s p$., having the ability to detoxify the pesticides such as DDVP, pyrethroids and chlorinated pesticide which was commonly used to control house flies population in the poultry excreta [42]. So that other microbes present in the FMC will acts on excreta for rapid decomposition and make it as manure. Pseudomonas fluorescens is one of the key commercial microbes which degrade the major toxic chlorinated pesticides like 2, 4-D Dichlorophenoxy acetic acid [64], and it's oxidizing tolerant efficiency which is help to tolerate all stress conditions [5].

Barker et al.,; Rothrock et al., [66],[ 67] reports microorganisms in poultry excreta, having revealed the number of pathogenic bacteria found at different depths of poultry excreta, which can potentially contaminate the poultry environment and are frequently associated with food borne outbreaks [68]. Composting of poultry excreta prior to the application to agricultural soils as a fertilizer is usually recommended to be pathogenic free in the final composts. Lin et al. [69] reported Lactobacillus fermentum strains showed antagonistic effect against the indicator bacteria found in poultry excreta. Rhizobium leguminosarum in addition to plant growth promotion, they can produce enzymes, polysaccharides, and antibiotics [70].

However, Dittoe et al. [40] reported that the colony formation of lactic acid bacteria could control the pathogenic population. FMC treatment in the present investigation is in accordance with the findings of Masuda et al. [41] who reported that concentration of lactic acid level increased in the substrate, and it prevents the multiplication of pathogenic microorganisms on organic waste products. FMC of the present investigation has two strains of lactic acid bacteria (Lactobacillus fermentum and Lactobacillus bifermentans) which could control the pathogenic microbes in poultry excreta. 
Bait formulations of the most virulent and aggressive strain of Beauveria bassiana (Bb 72) were studied by Lecuona et al.,[71], they reported Beauveria bassiana (Bb 72) strain was more than $97 \%$ virulent against adult Musca domestica, together with its effectiveness in conidial production, indicating this strain has been used as mycoinsecticide. FMC contains Beauveria bassiana strain having the ability to control larval, pupal and adult stages of Musca domestica population present in the poultry excreta.

The above issues are carefully handled in early stages of the FMC treatment in the poultry farm because first we should control those obstacles for boosting up the composting because (i) insecticides that prevent the natural microbial decomposition, (ii). Pathogens that infect workers of poultry farms, and also the birds, (iii) and pathogenic carrier of Musca domestica. The above task was successfully completed in the poultry farm, is suitable for proliferation natural decomposing microbes that will apply in the form of enriched FMC and BFM.

Poultry feeds contain dietary fiber mainly of cellulosic, non-cellulosic polysaccharides and lignin. These components are highly resistant to digestion by alimentary enzymes or absorbed in the bloodstream. The rate of biodegradation of an organic material present in poultry excreta depends on the concentration of lignin content. Francou et al. [72] reported that the cellulose constituents of the fiber and lignin are the key material responsible for slowing down the decomposition of organic matter. The well-known cellulolytic efficiency of the Cellulomonas fimi studied by Sandercock et al., [73] will effectively decompose the cellulose material present in excreta of poultry. FMC solution also containing zygomycetes fungi Mucor sp. had been found to exhibit high biodegrading activity in poultry excreta due to the secretion of amylase and cellulase enzymes that were responsible for the cellulolytic process [74],[75]. Kapich et al.,[76] Phanerochaete chrysosporium having the ability to synthesis of high protein could be influenced by extracellular production of ligninolytic peroxidases enzymes leading to the conversion of complex lignocelluloses into sugar to simple forms that are easily consumed by yeast cells found in poultry excreta previously sprayed by FMC.

Formulated microbial consortium is also deemed an alternative approach to prevent the drop in $\mathrm{pH}$, and thereby the efficiency of poultry excreta composting. A major problem facing many poultry farms is odour emission into the surrounding environment due to incomplete decomposition of poultry excreta. One of the important characteristics of waste composting is a decrease in $\mathrm{pH}$ in the premature stages of composting [77], because poultry excreta contain abundant and easily decomposable sugary substances, fatty materials, and grease. Degradation of these materials produces a large amount of intermediate acidic by-products, organic acids, which leads to the reduced $\mathrm{pH}$ of the composting substrate at the initial stage of waste composting [78], low pH values could lead to the slow down the rate of decomposition of organic matter, and thereby lower the efficiency of composting due to reduce the activity of microbes. $\mathrm{pH}$ of initial stage composts are slightly alkaline in this study (Fig. 2) could control the foul odor due to proper decomposing of organic matter in an initial stage of composting.

At the maturity stage of PM - III FMC+BFM treated in the present study the $\mathrm{pH}$ was almost neutral and is good for plants having the ability to uptake nutrients from compost added soil. This was confirmed by Brown et al.,[79], reported $\mathrm{N}, \mathrm{K}$, in cultivated soil are more available within soil $\mathrm{pH} 6.5$ to 8 , Phosphorus is most available within soil $\mathrm{pH} 5.5$ to 7.5 . $\mathrm{pH}$ value of the PM- III treated with FMC+BFM was almost alkaline in initial stage to support boost up the decomposing microbes (pH.8.7 Fig. 2) at maturity period of $84^{\text {th }}$ day got almost neutral (pH.7.4 Fig. 2) this condition supports the plants to uptake nutrients, it could possibly due to the compost stabilized at maturity stage which may be due to the buffering nature of humic substances[80].

The electrical conductivity of all the composts showed a change of an increase (Fig.3) from the initial level to maturity stages of poultry composts. An increased electrical conductivity could be due to the degradation of organic matter, and release of different mineral salts in available forms, which they attributed that were generated during microbial decomposition [81]. Guoxue et al.,[82], were also observed a gradual increase in EC of organic matter under decomposition, so that the soluble status of PM - III treated with FMC+BFM was on the higher side.

Poultry composting using the microbial consortium is also an effective and inexpensive means of stabilizing organic matter [83]. The organic carbon content during composting of all composts declined drastically from the initial level to maturity stage (Fig.4). Suthar and Singh [84] reported that the composting process causes a significant decline in organic carbon of the waste decomposition system. This was due to enhanced oxidation of organic carbon, which might be a result of microbial decomposition of organic substrates [85]. Loss of dry matter in the form of carbon dioxide due to the activities of microbes and evaporation of moisture content also could account for the decline in organic matter over the period of composting. This was conformed to the results reported by Sangodoyin and Amori [86]. A decrease of organic carbon served as an indicator of compost maturity and stability [87]. The percentage of organic carbon in all the composts decreases significantly during composting. According to Garg and Kaushik [88] a large fraction of the total organic carbon was lost as $\mathrm{CO}_{2}$ by the end of the composting through microbial respiration and mineralization of organic matter causing increase in total nitrogen [89].

In consequence of changes in the $\mathrm{C}: \mathrm{N}$ ratios of compost mixtures were high at the premature stages which 
decreased substantially during the composting period indicating the maturity of the composts(Fig.4). The C:N ratio reflects the spectra of changing carbon and nitrogen concentration of the substrate material during the process of composting. The compost PM - III FMC+BFM treated which showed higher potentialities in narrowing the C:N ratios of the composts. The $\mathrm{C}: \mathrm{N}$ ratio is considered as one of the simple indices to evaluate any organics for its fitness for application, and it is the index traditionally used to establish the stabilized maturity of compost [90]. The relevance of the C:N ratio relies on the fact that a decrease in the ratio implies an increase in the degree of organic matter humification [91].

In our study microorganisms present in FMC and FMC+BFM played a vital role in improving the major nutrients of NPK had increased greatly in PM - II and PM - III treatment(Fig.5\&6). The available forms of NPK could be due to the fact that the organic acids, carbonic acid and chelating substances produced during the course of decomposition might have helped in the liberation of macronutrients[92].

High protein source of poultry excreta is the best for boosting the nitrogen level of poultry manure. Poultry feeds are composed primarily of a mixture of cereal grains of wheat and maize, broken rice, sorghum, soybean meal, meat and bone meal, blood meal, feather meal and fish meal is the dominant protein supplement [93]. Poultry manure nitrogen comes from undigested fiber, bacterial cell walls and sloughed intestinal tissues [94]. Bernal et al. [90] who indicated that the nitrogen usually increases during the composting process when volatile solid loss is greater than the loss of ammonia. The total nitrogen of all composts was increased from its initial level. Good composting process reduces ammoniacal nitrogen and increases available nitrogen. This is due to the fact that combinations of organic additives are capable of immobilizing inorganic ammonia into organic forms [95]. In the present investigation composts PM - II and PM - III except PM - I control could achieve enhancement of available nitrogen. In PM - I control higher concentration of $\mathrm{NH}^{4+}$ affected the occurrence of nitrification from relatively immobile $\mathrm{NH}^{4+}$ to mobile $\mathrm{NO}_{3}{ }^{-}$as suggested by Bramley and White [96]. Nitrogen in poultry excreta can be effectively conserved by composting with $\mathrm{FMC}+\mathrm{BFM}$ treatment will be highly useful to the farmers.

Phosphorus is an important key element for normal muscle growth, and egg formation of the poultry birds. The diets sources of low concentrations availability of total phosphorus are cereal grains and their by-products but bone meal has relatively high bioavailable phosphorus [97]. The increase in available phosphorus could be due to the fact that the organic acids, carbonic acid and chelating substances, produced during the course of decomposition might have helped in the liberation of Phosphorus [98]. It is a second important plant nutrient because plants cannot grow without a reliable supply of P[99]. Bacillus megaterium and Psudomonas fluorescens in $\mathrm{FMC}+\mathrm{BFM}$ having the ability to convert insoluble inorganic $\mathrm{P}$ into a soluble form through the process of solubilization, organic $\mathrm{P}$ by the process of mineralization and to releasing low molecular mass organic acids, and phosphatases [100]. Rhizobium leguminosarum species present in BFM solution which increases the growth substances of inorganic phosphates by the process of solubilization to poultry manure [101].

The release of potassium from poultry manures was gradually increased from $4^{\text {th }}$ week of analysis (Fig.5\&6). Potassium is the third key macronutrient of poultry manure that helps plants resist disease and plays an important role in increasing crop yields, protects the plant when the cold weather, strengthening its root system and preventing wilt [102],[103]. Potassium solubilizing bacteria of Frateuria aurantia in FMC+BFM can solubilize K-bearing minerals and convert the insoluble $\mathrm{K}$ to soluble forms of $\mathrm{K}$ through the production, and secretion of organic acids in poultry excreta available to plant uptake, and also converted as potassium biofertilizer [104]. Metting [105] suggested that the enhancement of potassium with time was due to mineralization of native carbon accompanied by a reduction in the total volume of the waste. Potassium in poultry manure of FMC+BFM is mostly present in the inorganic form. This means that $\mathrm{K}$ in poultry manure is similar to commercial fertilizer that is readily available for plant uptake.

The present study offers high hope in converting poultry excreta into effective manure for agriculture. The poultry composted manure treated with FMC and FMC+BFM is a complete plant nutrient that can be used as an alternative source of chemical fertilizer in agriculture, its ability to support plant growth by supplying essential macro plant nutrients of NPK. This treatment of poultry excreta may provide a beneficial alternative method for handling excreta due to holding the nutrients in the manure and completely reducing excreta volume. Apart from the quality, the PM - III nature and rate of decomposition and volume reduction rate are also very high when compared to PM - I and PM - II. In comparison to PM- I control and PM- II the FMC treated, the PM - III FMC+BFM treated have less organic carbon, more NPK. Any type of organic matter could be composted with FMC+BFM technology, as there is no development of offensive odor, more than $80 \%$ reduction was observed within 25 days. Properly managed, land-applied manures from poultry excreta can provide valuable nutrients, and organic matter for agricultural production systems without harming their environment and health of the farmers and public. FMC+BFM solution speeds up the poultry composting process, keeps away insects and pests in the poultry farm. Treated manure may help to enhance soil fertility, plants to absorb nutrients from the soil, and enhance agricultural yield. 


\section{Conclusion}

The present investigation application of formulated microbial consortium along with biofertilizer microorganism on poultry excreta has shown tremendous improvement in quality of the manure in an environmentally friendly manner. The evaluation of poultry manure by nutrient analysis revealed that the addition of $\mathrm{FMC}+\mathrm{BFM}$ gave good quality compost as compared with non-treated and FMC alone treated poultry excreta. The FMC+BFM treated excreta, reduces the pollution rate and enhances the decomposition rate and enrichment of macronutrients. After the experiment, it shows that the FMC along with BFM was working effectively and is an excellent source for agriculture.

\section{Acknowledgments}

The authors thank the proprietors of Mr. S. Trinadha Reddy and Dr. Anuratha of Dhanalakshmi poultry complex located in Bewoor Koppal, Karnataka state, India for giving their farms for carrying out the entire research work successfully.

\section{REFERENCES}

[1] J. Chastain, JJ. Camberato, JE. Albrecht. Nutrient content of livestock and poultry manure. Climate Change Central, Clemson University, USA. 36p. 2001.

[2] KY. Chan, L. Van Zwieten, L. Meszaros, A. Downie, S. Joseph. Using poultry litter biochars as soil amendments, Australian J. Soil Res. Vol.46. 437-444.2008.

[3] RD. Harmel, D.R. Smith, R.L. Haney, M. Dozier. Nitrogen and phosphorus runoff from cropland and pasture fields fertilized with poultry litter. J. Soil and Water. Conserv. Vol.64. No.6. 400-412.2009.

[4] SN. Dauda, L. Aliyu, UF. Chiezey. Effect seedling age at transplant and poultry manure on fruit yield and nutrients of garden egg (S. gilo L.) varieties. J. Tropical Sci. Vol.5. No.2. 38-41. 2005.

[5] D. Drozdz, K. Wystalska, K. Malinska, A. Grosser, A. Grobelak, M. Kacprzak. Management of poultry manure in Poland - Current state and future perspectives. J. Environ. Mgt. Vol.264. 1-16.2020.

[6] A. Adeli, H. Tewolde, KR. Sistani, DE. Rowe. Broiler litter fertilization and cropping system impacts on soil properties. Agronomy J. Vol.101. No6. 1304-1310.2009.

[7] EO. Beckman. Organic fertilization: vegetable farming luxury or necessity. Tech. Commun. ISHA, Vol.29, 247.1973.

[8] AE. Eneji, S. Inanaga, X. Li, P. An, J. Li, L. Duan, Z. Li. Effectiveness of mulching vs. incorporation of composted cattle manure in soil water conservation for wheat based on eco-physiological parameters. J. Agronomy and Crop Sci. Vol.194. 26-33.2008.

[9] TM. Agbede, SO. Ojeniyi. Tillage and poultry manure effects on soil fertility and sorghum yield in southwestern Nigeria. Soil and Tillage Res. Vol.104. 74-81.2009.

[10] KO. Sanni, JM. Adesina. Response of water hyacinth manure on growth attributes and yield of Celosia argentea $\mathrm{L}$ (Lagos Spinach). Journal of Agricul. Technol. Vol. 8. No.3. 1109-1118.2012.

[11] PK. Pindi and SDV. Satyanarayana. Liquid microbial consortium- A potential tool for sustainable soil health. J Biofertil Biopestici. Vol.3. No.4. 1-9.2012.

[12] AN. Sharpley, S. Herron, T. Daniel. Overcoming the challenges of phosphorus-based management challenges in poultry farming. J. Soil and Water Conserv. Vol.58. 30-38. 2007.

[13] ASABE. Manure production characteristics. American Society of Agricultural and Biological Engineers. St. Joseph, MI. 2005.

[14] DE. Kaiser, AP. Mallarino, MU. Haq. Runoff phosphorus loss immediately after poultry manure application as influenced by the application rate and tillage. J. Environ. Qual. Vol.38. 299-308.2009.

[15] RD. Harmel, HA. Torbert, BE. Haggard, R. Haney, M. Dozier. Water quality impacts of converting to a Poultry litter fertilization strategy. J. Environ. Qual. Vol.33. 2229-2242.2004.

[16] V. Rodic, L. Peric, M. Dukic-Stojcic, N. Vukelic. The environmental impact of poultry production. Biotechnol. in Animal Husbandry. Vol.27. No.4. 1673-1679.2011.

[17] PD. Millner. ISBN 012404686X, 9780124046863. Manure management. In: GMS, Solomon EB, RKM (eds). The produce contamination problem: causes and solution. Academic, New York, pp. 79-104. 2009.

[18] C. Nelson, J. Lamb. Final Report: haubenschild farms anaerobic digester. The Minnesota project, St. Paul, MN., pp 35. 2002

[19] S. Myszograj, E. Puchalska. Waste from rearing and slaughter of poultry - treat to the environment or feedstock for energy. Environ. Med. Vol.15. No.3. 106-115.2012.

[20] SS. Schiffman. CM. Williams. Science of odor as a potential health issue. J.Environ. Qual. Vol.34, 129-138.2005.

[21] RI. Mackie, PG. Stroot, VH. Varel. Biochemical Identification and Biological Origin of Key Odor Components in Livestock Waste. J. Anim. Sci. Vol.76. 1331-1342.1998.

[22] BP. Kelleher, JJ. Leahy, AM. Henihan, TF. O’Dwyer, D. Sutton, MJ. Leahy. Advances in poultry litter disposal technology - a review. Biores. Technol. Vol.83. 27-36.2002.

[23] NI. Krylova, RE. Khabiboulline, RP. Naumova, MA. Nagel. The influence of ammonium and methods for removal during the anaerobic treatment of poultry manure. J. Chem. Technol. Biotechnol. Vol.70. 99-105.1997.

[24] VP. Aneja, J. Blunden, K. James WH. Schlesinger R. 
Knighton W. Gilliam G. Jennings, D. Niyogi, S. Cole. Ammonia Assessment from Agriculture: U.S. Status and Needs. J. Environ. Qual. Vol.37. 515-520.2008.

[25] NS. Bolan, AA. Szogi, T. Chuasavathi, B. Seshadri, MJ. Rothrock, P. Panneerselvam. Uses and management of poultry litter. World's Poultry Sci. J, Vol. 66. 673-698. 2010.

[26] KL. Cook, MJ. Rothrock JG. Warren, K. Sistani, PA. Moore. Effect of alum treatment on the concentration of total and ureolytic microorganisms in poultry litter. J. Environ. Qual. Vol.37. 2360-2367. 2008.

[27] MJ. Rothrock, KL. Cook, JG. Warren, K. Sistani. The effect of alum addition on microbial communities in poultry litter. Poult. Sci. Vol.87. 1493-1503. 2008.

[28] N. Lovanh, KL. Cook, M.J. Rothrock, DM. Miles, K. Sistani. Spatial shifts in microbial population structure within poultry litter associated with physicochemical properties. Poult. Sci. Vol.86. 1840-1849. 2007.

[29] S. Goyal, SK. Dhull, KK. Kapoor. Chemical and biological changes during composting of different organic wastes and assessment of compost maturity. Bioresour. Technol. Vol.96. 1584-1591. 2005

[30] V. Marchioro, L. Ricardo R. Steinmetz, C. Andre, D. Amaral, TC. Gaspareto, H. Treichel and A. Kunz. Poultry litter solid state anaerobic digestion: Effect of digestate recirculation intervals and substrate / inoculum ratios on process efficiency. Front. Sustain. Food. Sys. Vol. 2. No.46. 1-10. 2018.

[31] S. Borowski, J. Domanski, L. Weatherley. Anaerobic co-digestion of swine and poultry manure with municipal sewage sludge. Waste Mgt. Vol.34. 513-521. 2014.

[32] BE. Liedl, J. Bombardiere, JM. Chatfield. Fertilizer potential of liquid and solid effluent from thermophilic anaerobic digestion of poultry waste. Water Sci. \& Technol. Vol.53. No.8. pp 69-79.2006.

[33] M. Budych-Gorzna, M. Smoczynski, P. Oleskowicz-Popiel. Enhancement of biogas production at the municipal wastewater treatment plant by co-digestion with poultry industry waste. Appl. Ener. Vol.161. 387-394. 2016.

[34] P. Abelhaa, I. Gulyurtlua, D. Boavidaa, JS. Barrosa, I. Cabritaa, J. Leahyb, B. Kelleherb, M. Leahyc. Combustion of poultry litter in a fluidised bed combustor. Fuel. Vol.82. 687-692. 2003.

[35] PA. Beohar, RK. Srivastava. Poultry waste management through vermicomposting employing exotic and indigenous species of earthworms. J. Soil Sci. Vol.1 No.1. 04-11. 2011.

[36] KV. Pradeepkumar, PS. Arunadevi, P. Myvizhi. Treatment and utilization of municipal solid waste as manure for agriculture through formulated microbial consortium along with bio fertilizer microorganisms. Adv. Zoo. Bot. Vol.8. No.5. 2020.

[37] DJ. Mishra, S. Rajvir, UK. Mishra, SS. Kumar. Role of Bio-Fertilizer in Organic Agriculture: A Review. Res. J. Rec. Sci. Vol.2. 39-41. 2013.

[38] DV. Pathak, M. Kumar. Microbial Inoculants as Biofertilizers and Biopesticides. D.P. Sing. Microbial Inoculants in Sustainable Agricultural Productivity. (Eds.), DOI 10.1007/978-81-322-2647-5 11. Spiringer India. 2016.
[39] HR. Pahren. CS. Clark. Microorganisms in municipal solid waste and public health implications. Critical Rev. Environ. Contl. Vol.17. 187-228.1987.

[40] DK. Dittoe, SC. Ricke, AS. Kiess. Organic acids and potential for modifying the avian gastrointestinal tract and reducing pathogens and disease. Front. Vet. Sci. Vol.5. No.216. 1-12.2018.

[41] S. Masuda, Y. Hara-Kudo, S. Kumagai. Reduction of Escherichia coli O157; H7 populations in soy sauce, a fermented seasoning". J. Food Protec. Vol.61. 657-661.1998.

[42] PG. Egland, J. Gibson, CS. Harwood. Reductive coenzyme A-Mediated pathway for 3-Chlorobenzoate degradation in the phototrophic bacterium Rhodopseudomonas palustris. Appl. Environ. Microbiol. Vol.67. No.3. 1396-1399.2001.

[43] KO, Duedu, C. French. Characterization of a Cellulomonas fimi exoglucanase/xylanase-endoglucanase gene fusion which improves microbial degradation of cellulosic biomass. Enzyme Microb. Technol. Vol.93. 113-121. 2016.

[44] IT. Paulsen, CM. Press, J. Ravel. Complete genome sequence of the plant commensal Pseudomonas fluorescens Pf-5. Nat. Biotechnol. Vol.23. 873-878.2005.

[45] J.Van Leeuwen, Z. Hu, TW. Yi, A.L. Pometto, B. Jin. Kinetic model for selective cultivation of microfungi in a microscreen process for food processing wastewater treatment and biomass production. Acta Biotechnol. Vol.23. 289-300.2003.

[46] J. Snetselaar, R. Andriessen, RA. Suer, AJ. Osinga, BGJ. Knols, M. Farenhorst. Development and evaluation of a novel contamination device that targets multiple life-stages of Aedes aegypti. Parasit \& Vect. Vol.7. 200.2014.

[47] L. Ke, Q. Wu, D. Zhang. Bioconversion of rape straw into a nutritionally enriched substrate by Ganoderma lucidum and yeast. African J. Biotechnol. Vol.10. 5648-5653.2011.

[48] V. Poonam, D. Ankur, C. Varsha, A. Jamaluddin. Studies on enzymatic potential fungi isolated from municipal solid waste in Jabalpur. Int. J. Rec. Sci. Res. Vol.6. No.8. 5927-5932.2015.

[49] M. Ardakani S. Mafakheri. Designing a sustainable agroecosystem for wheat (Triticum aestivum L.) production. J. Appl. Environ. Biol. Sci. Vol.1. 401-413.2011.

[50] M. Turan, M. Gulluce, W.N. Von, F. Sahin. Yield promotion and phosphorus solubilization by plant growth-promoting rhizobacteria in extensive wheat production in Turkey. J. Plant. Nutr. Soil Sci. Vol.175. 818-826.2012.

[51] K. Kaur, S. Goyal, KK. Kapoor. Impact of Organic Fertilizers with and without Chemical Fertilizers on Soil Chemical Properties and the Establishment of Nitrogen-Fixing Bacteria in the Rhizosphere. Microbes Environ. Vol. 23. No.4. 313-316.2008.

[52] M. Irfan, U. Asghar, M. Nadeem, R. Nelofer, Q. Syed. Optimization of process parameters for xylanase production by Bacillus sp. in submerged fermentation. J. Radiation Res. Appl. Sci. Vol.9. 139-147. 2016.

[53] DV. Subhashini. Growth promotion and increased potassium uptake of tobacco by potassium-mobilizing bacterium Frateuria aurantia grown at different potassium levels in 
vertisols. Commun. Soil Sci. plant Anal. Vol.46. No.2. 2015.

[54] American Public Health Association. Standard methods for the examination of water and wastewater. $\left(20^{\text {th }}\right.$ ed.), American Public Health Association, Washington DC.1998.

[55] CA. Black. Methods of Soil Analysis, Vol. 2. American Society of Agronomy, USA.1965.

[56] AI. Vogel. A textbook of quantitative inorganic analysis. Longman, Green.1961.

[57] G. Wen, TE. Bates, RP. Voroney, JP. Winter, MP. Schellenbert. Comparison of Phosphorus availability with application of sewage sludge, sludge compost, and manure compost. Commu. Soil Sci. Plant Anal. Vol.28. 1481-1497.1997.

[58] ML. Jackson. Soil chemical analysis. Prenice-Hall, London.1968.

[59] DR. Edwards, TC. Daniel. Environmental Impacts of On-Farm Poultry Waste Disposal A Review. Biores. Technol. Vol.41. 9-33.1992.

[60] CFK. Hansen, TR. Batterson, CD. Mcnabb. The role of chicken manure in the production of Nile tilapia, Oreochromis niloticus (L.). Aqua. Res. Vol. 24. No.4. 483-4931993.

[61] SM. Tiquia, NFY. Tam. Elimination of phytotoxitcity during cocomposting of spent pig manure, sawdust litter and sludge. Biores. Technol. Vol.65, 43-49.1998.

[62] X. Luo, D. Zhang, X. Zhou, S. Zhang, Y. Liu. Biodegradation of fenpropathrin by Rhodopseudomonas $s p$. strain PSB07 - 21 cultured under three different growth modes. J Basic Microbiol. 2019, Vol.59. 591-598.2019.

[63] Selimoglu, O. Ayten, A. Munevver, IA. Meysun. Biosorption of Dichlorvos by the anaerobic photosynthetic bacterium Rhodopseudomonas palustris NU51. Fresenius Environmental Bulletin. Vol.20. 1183-1189. 2011.

[64] G. Santacruz, ER. Bandala, LG. Torres. Chlorinated pesticides (2,4-D and DDT) biodegradation at high concentrations using immobilized Pseudomonas fluorescens. J. Environ. Sci. Hlth. Vol.40. 571-583. 2005.

[65] LSV. Overbeek, L. Eberl, M. Givskov, S. Molin, JDV. Elsas. Survival of, and induced stress resistance in, carbon-starved Pseudomonas fluorescens cells residing in soil. Appl. Environ. Microbiol. Vol.61. No.12. 4202-4208. 1995.

[66] KJ. Barker, JL. Purswell, JD. Davis, HM. Parker, MT. Kidd, CD. McDaniel, AS. Kiess. Distribution of bacteria at different poultry litter depths. Int. J. Poultry Sci. Vol.9. No.1. 10-13. 2010.

[67] MJ. Rothrock, ML. Davis, A. Locatelli, A. Bodie, TG. McIntosh, JR. Donaldson, SC. Ricke. Listeria occurrence in poultry flocks: Detection and potential implications. Front Vet Sci. Vol.4. 1-7. 2017.

[68] HN. Chinivasagama, M. Redding, G. Rungec, PJ. Blackalla. Presence and incidence of food-borne pathogens in Australian chicken litter. British Poul. Sci. Vol.51. No.3. 311-318.2010.

[69] WH. Lin, B. Yub, SH, Jangc, HY. Tsend. Different probiotic properties for Lactobacillus fermentum strains isolated from swine and poultry. Anaerobe. Vol.13. 107-113. 2007.

[70] A. Patil, A. Kale, G. Ajane, R. Sheikh, S. Patil. Plant Growth-Promoting Rhizobium: Mechanisms and Biotechnological Prospective. AP. Hansen et al. (eds.), Rhizobium Biology and Biotechnology, Soil Biology 50, DOI 10.1007/978-3-319-64982-5_7. Springer International Publishing AG 2017.

[71] RE. Lecuona, M. Turica, F. Tarocco, DC. Crespo. Microbial control of Musca domestica (Diptera: Musciadae) with selected strains of Beauveria bassiana. J. Med. Entomol. Vol.42. 332-336. 2005.

[72] C. Francou, M. Lineres, S. Derenne, M. Le Villio-Poitrenaud, S. Houot. Influence of green waste, biowaste and paper-cardboard initial ratios on organic matter transformations during composting. Biores. Technol. Vol.99. 8926-8934.2008.

[73] LE. Sandercock, A. Meinke, NR. Gilkes, DG. Kilburn, RAJ. Warren. Degradation of cellulases in cultures of Cellulomonas fimi. FEMS Microbiol. Let. Vol.143. 7-12. 1996.

[74] SN. Chinedu, VI. Okochi, HA. Smith, O. Omidiji. Isolation of cellulolytic microfungi involved in wood-waste decomposition: prospects for enzymatic hydrolysis of cellulosic wastes. Int. J. Biomed. Hlth Sci. Vol.1. No.2. 1-8.2005.

[75] V. Poonam, D. Ankur, C. Varsha, A. Jamaluddin. Studies on enzymatic potential fungi isolated from municipal solid waste in Jabalpur. Int. J. Rec. Sci. Res. Vol.6. No.8. 5927-5932.2015.

[76] AN. Kapich, BA. Prior, A. Botha, S. Galkin, T. Lundell, A. Hatakka. Effect of lignocellulose-containing substrates on production of ligninolytic peroxidases in submerged cultures of Phanerochaete chrysosporium ME-446. Enzyme and Microbial Technol. Vol.34. 187-195.2004.

[77] C. Sundberg, S. Smars, H. Jonsson. Low pH as an inhibiting factor in the transition from mesophilic to thermophilic phase in composting. Biores Technol. Vol.95. $145-150.2004$.

[78] C. Song, Y. Zhang, X. Xia, H. Qi, M. Li, H. Pan, B, Xi. Effect of inoculation with a microbial consortium that degrades organic acids on the composting efficiency of food waste. Microbial Biotechnol. Vol.11. No.6. 1124-1136.2018.

[79] TT. Brown, RT. Koenig, DR. Huggins, JB. Harsh, RE. Rossi. Lime effects on soil acidity, crop yield, and aluminum chemistry in direct-seeded cropping systems. Soil Sci. Soc. Am. J. Vol.72. No.3. 634-640.2008.

[80] PS. Arunadevi. Sustainable waste management strategy for dairy industry. Ph.D., Thesis. Bharathiar University, Coimbatore, TN. India. 2010.

[81] Kaviraj, S. Sharma. Municipal solid wastes management through vermicomposting employing exotic and local species of earthworm. Bioresour. Technol. Vol.90. No.2. $169-173.2003$.

[82] LI. Guoxue, F. Zhang, Y. Sun, JWC. Wong, M. Fang. Chemical evaluation of sewage composting as mature indicator for composting process. Water Air Soil Sludge 
Pollut. Vol.132. 333 - 345.2001.

[83] CG. Golueke. Biological reclamation of solid wastes. Rodale, Emmaus, Pennsylvania. 249 p. 1977.

[84] S. Suthar, S. Singh. Vermicomposting of domestic waste by using two epigeic earthworms (Perionyx excavatus and Perionyx sansibaricus). Int. J. Environ. Sci. Tech. Vol.5. No.1. 99-106.2008.

[85] MP. Bernal, JA. Alburquerque, R. Moral. Composting of animal manures and chemical criteria for compost maturity assessment. A review. Bioresour. Technol. Vol.100. 5444-5453.2009.

[86] AY. Sangodoyin, AA. Amori. Aerobic composting of cassava peels using cowdung, sewage sludge and poultry manure as supplements. European Int. J. Sci. Technol. Vol.2. No.8. 22-34.2013.

[87] Y. Inbar, Y. Hadar, Y. Chen. Recycling of cattle manure: the composting process and characterization of maturity. $\mathrm{J}$ Environ. Qual. Vol.22. 857-863.1993.

[88] VK. Garg, P. Kaushik. Vermistabilization of textile mill sludge spiked with poultry droppings by an epigeic earthworm Eisenia foetida. Bioresour. Technol. Vol.96. 1063-1071.2005.

[89] JE. Hobbie, EA. Hobbie. Microbes in nature are limited by carbon and energy: the starving-survival lifestyle in soil and consequences for estimating microbial rates. Front Microbiol.Vol.4. 1-11.2013.

[90] M. Bernal, A. Navarro, M. Sanchez-Monedero, A. Roig, J. Cegarra. Influence of sewage sludge compost stability and maturity on carbon and nitrogen mineralization in soil. Soil Biol. Biochem. Vol.30. No.3. 305-313. 1998.

[91] D. Raja, RS. Antilb. Evaluation of maturity and stability parameters of composts prepared from farm wastes. Arch. Agron. Soil Sci. Vol.58. No.8. 817-832.2012.

[92] ET. Alori, BR. Glick, OO. Babalola. Microbial Phosphorus Solubilization and Its Potential for Use in Sustainable Agriculture. Front. Microbiol.Vol.8. No. 971. 1-8.2017.

[93] D. Meeker, CR. Hamilton. An overview of the rendering industry. Essential Rendering: All about the Animal By-products Industry. 1-16. 2006.

[94] J. Sittiya, K. Yamauchi, W. Nimanong, N. Thongwittaya. Influence of levels of dietary fiber sources on the performance, carcass traits, gastrointestinal tract development, fecal ammonia nitrogen, and intestinal morphology of broilers. Braz. J. Poult. Sci. Vol.22. No.1.
$1-8.2020$.

[95] P. Zhang, RK. Dumroese, JR. Pinto. Organic or Inorganic Nitrogen and Rhizobia Inoculation Provide Synergistic Growth Response of a Leguminous Forb and Tree. Front. Plant Sci., Vol.10. 1-13.2019.

[96] RGV. Bramley, RE. White, An analysis of variability in the activity of nitrifiers in a soil under pasture. I. Spatially dependent variability and optimum sampling strategy. Australian J. Soil Res. Vol.29. 95-108.1991.

[97] X. Li, D. Zhang, TY. Yang, WL. Bryden. Phosphorus bioavailability: A key aspect for conserving this critical animal feed resource with reference to broiler nutrition. Agriculture. Vol.6. No.25. 1-15.2016.

[98] SH. Chien. Dissolution of phosphate rock in acid soils as influenced by nitrogen and potassium fertilizers. Soil Sci. Vol.127. 371-376.1979.

[99] DP. Schachtman, RJ. Reid, SM. Ayling. Phosphorus uptake by plants: from soil to cell. Plant Physiol. Vol.116. 447-453.1998.

[100] SB. Sharma, RZ. Sayyed, MH. Trivedi, TA. Gobi. Phosphate solubilizing microbes: sustainable approach for managing phosphorus deficiency in agricultural soils. Springer Plus. Vol.2. No.587.1-14. 2013.

[101] RC. Dubey, DK. Maheshwari, H. Kumar, K. Choure. Assessment of diversity and plant growth promoting attributes of rhizobia isolated from Cajanuscajan L. African. J. Biotechnol. Vol.9. 8619-8629.2010.

[102] M. Hasanuzzaman, MHMB. Bhuyan, K. Nahar, S. Hossain, JA. Mahmud, S. Hossen, AAC. Masud, Moumita, M. Fujita. Potassium: A Vital Regulator of Plant Responses and Tolerance to Abiotic Stresses. Agronomy. Vol.8. No.31. 1-29.2018.

[103] K. Prajapati, HA. Modi. The importance of potassium in plant growth - A review. Indian Journal of Plant Sciences. 2012 Vol.1. No.02-03. 177-186.2012.

[104] E. Velazquez, LR. Silva, MHR. Bahena, A. Peix. Diversity of potassium-solubilizing microorganisms and their interactions with plants. V.S. Meena et al. (eds.), Potassium solubilizing microorganisms for sustainable agriculture, DOI 10.1007/978-81-322-2776-2_7, pp.99-110.Springer India 2016.

[105]FB. Metting. Soil microbial ecology-Application of agricultural and environmental management. Marcel Dekkar, New York.1993. 